\title{
UK CONSTRUCTION COMPANIES' STRATEGIES IN THE FACE OF BUSINESS CYCLES
}

\author{
Les RUDDOCK ${ }^{\text {a,*, Amir KHEIR a , Steven RUDDOCK }}{ }^{\text {b }}$ \\ a School of the Built Environment, University of Salford, Salford M5 4WT, UK \\ ${ }^{b}$ Grenfell-Baines School of Architecture, Construction and Environment, University of Central Lanca- \\ shire, Preston PR1 2HE, UK
}

Received 17 December 2012; accepted 10 July 2013

\begin{abstract}
Firms in the construction industry have always had to deal with the challenges of the economic cycle and develop strategies to deal with the resulting fluctuations in their business environment. In the context of the 2008-2011 double-dip recession in the UK, the results of a survey targeting the top one hundred construction companies in the UK are reported here. This research is particularly intended to assess whether the strategies of large companies in the construction sector, when faced with the issues associated with the variation in the economic cycle, have changed since the previous business cycle (i.e. the 1986-1990 boom followed by the 1990-1991 recession). The survey reveals the challenges that companies have faced, reports on company behaviour and on the policies adopted. While there are many similarities between policies adopted during the recessionary periods of the two cycles, the research found notable changes in attitudes towards diversification, human resource management and price bidding.
\end{abstract}

KEYWORDS: Construction companies; Economic cycle; Impact; Recession; Strategy

\section{INTRODUCTION}

Construction is an important sector of the economy and the impact of changes in the overall levels of economic activity on the construction sector can be gauged by the fact that the size of the 'broad' construction sector, based on a homogenised International Standard Industrial Classification (2008), can constitute around 15-20\% of Gross Domestic Product (GDP) for developed countries such as the UK (Carassus et al. 2006; L. Ruddock, S. Ruddock 2009). Consequently, an economic recession has a huge effect on the construction industry, more so than most other industries. In 2008, construction activity diminished at its highest rate since records began (Office for National Statistics 2012). The biggest decline was recorded in house building with the civil engineering and commercial subsectors also falling at record levels.

Dating recessions is an imprecise science and much depends on the definition being applied.

\footnotetext{
* Corresponding author. E-mail: L.Ruddock@salford.ac.uk
}

There is no universally accepted definition but a technical definition of two successive quarters of falling GDP has gained some broad acceptance (National Bureau of Economic Research 2012). On this basis, the UK economy was in recession in 1990-1992 and 2008-2009 with the latter recessionary period being followed closely by another recessionary period commencing 2011 Q3 to constitute a double-dip recession. Economic Review data (Office for National Statistics 2013) indicated that the UK economy narrowly avoided a triple-dip recession in Q1 2013. Overall growth, though very weak, was positive and construction was noted to be one of the slow growing sectors still 18.9\% below its pre recession levels in Q1 2008. Cyclical fluctuations are a characteristic of economic growth patterns as is the intrinsic relationship between the level of construction activity and the stage of the business cycle (Barras 2009) i.e. construction activity increases during the growth part of the business cycle and decreases during the recessionary period of the business cycle. 
During a recession, a significant decline in activity spreads across the economy and, similarly, during an expansion (or 'boom' period), economic activity rises substantially and affects all sectors. The peak of an expansion dates the beginning of a downturn. Likewise, the trough of a recession is the point in time at which GDP falls to its lowest level before it begins to rise again, meaning that the trough determines the beginning of an expansion (National Bureau of Economic Research 2012). The severity of a recession can be measured in several ways but the peak to trough falls in output give a single measure of the loss in output in a recession. On this basis, the recent downturn in the economy has been more severe than the previous. For the early 1990s recession (1990 Q3 to 1992 Q2), the peak to trough fall in GDP was $2.5 \%$ but during the 2008 Q2 to 2009 Q3 recessionary period, it was $6.4 \%$ (Chamberlin 2010).

Figure 1 shows the quarterly change in GDP for a period incorporating both these recessions.

The effects of the economic cycle on construction activity can be seen in the changing level of orders for new construction work in Table 1. During the early 1980 s, the boom in the economy resulted in a growth of construction orders from $£ 43.3$ bn to $£ 74.8$ bn before falling back to $£ 52.1$ bn during the recession in 1992. During the next growth phase, construction orders grew to $£ 70.0$ bn in 2006 before declining, as a result of the recession, to $£ 42.6$ bn in 2011. The fact that the recession in 2008 was deeper than 1990 implies that construction compa- nies' strategic policies during the more recent recession might be considered even more crucial than those in the earlier one.

The demand for building activity is a derived demand, the level of which is mainly exogenously determined (Gruneberg, Ive 2000). To respond to changes in demand from falling economic activity, the industry must have a very high degree of flexibility and this needs to be reflected in a firm's business strategy. In the 2008-2009 recession, the contribution of the fall in construction sector output to the overall fall in GDP was almost $0.8 \%$ i.e. about one eighth of the total. Like other recessions in the UK and other developed countries, this one was characterised by sharp falls in residential investment, industrial production, housing and equity prices with a decline in consumption and a decrease in employment rates (Classessens et al. 2009; Dale 2009).

This research focuses on the 2008-2009 recession and also considers how approaches by large construction companies to deal with the threats of this downturn compare to the strategies employed in the previous one.

The main aim of the research is to discover how policies adopted by construction companies have changed and evolved from construction companies' practices of twenty years ago. Reference is also made to other sectors of the economy, experiences from other countries and underpinning research into management strategies in response to business cycles.

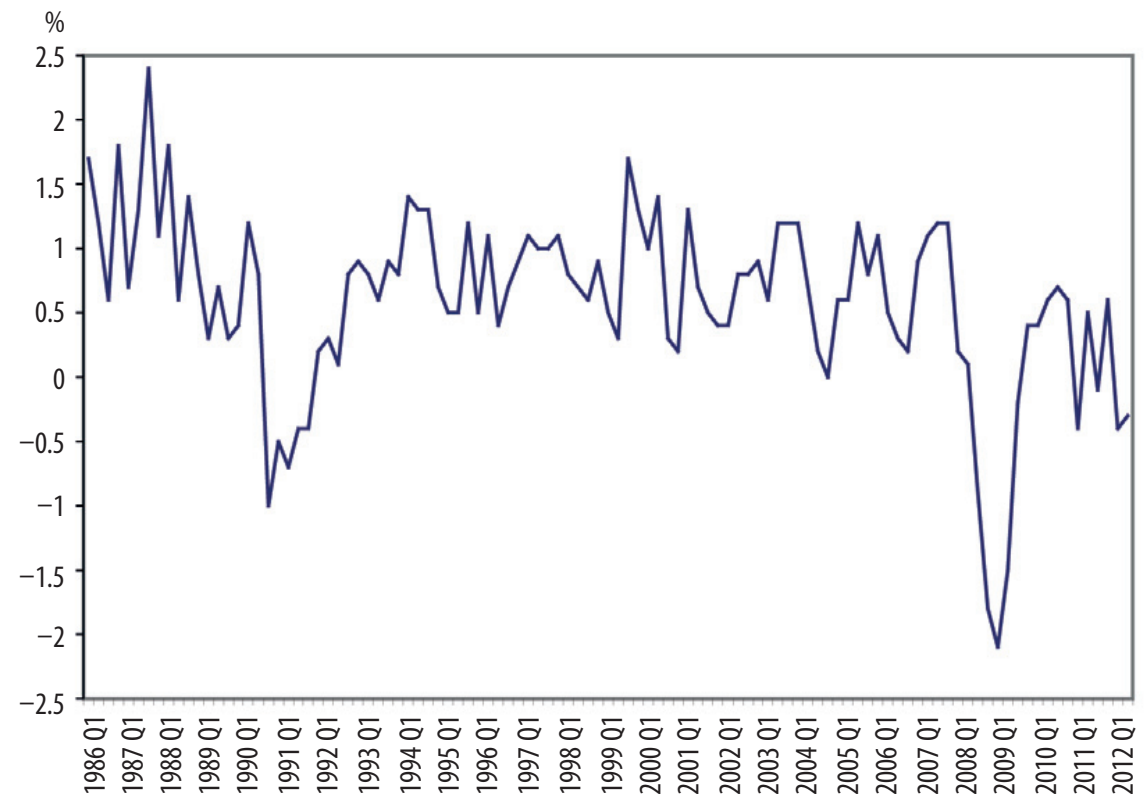

Fig. 1. UK GDP 1986 Q1 - 2012 Q1: Quarter on quarter growth (Office of National Statistics 2012) 
Table 1. Volume of orders for new construction by main contractors (1981-2011) at 2005 constant prices (Office of National Statistics 2012)

\begin{tabular}{|c|c|c|c|c|}
\hline$£$ Million & New housing & Other new work & All new work & Annual growth \\
\hline 1981 & 13,898 & 29,411 & 43,310 & $5.7 \%$ \\
\hline 1982 & 19,762 & 28,635 & 48,397 & $11.7 \%$ \\
\hline 1983 & 24,501 & 32,172 & 56,673 & $17.1 \%$ \\
\hline 1984 & 21,931 & 35,464 & 57,395 & $1.3 \%$ \\
\hline 1985 & 22,520 & 34,070 & 56,590 & $-1.4 \%$ \\
\hline 1986 & 24,095 & 37,192 & 61,288 & $8.3 \%$ \\
\hline 1987 & 25,402 & 46,293 & 71,695 & $17.0 \%$ \\
\hline 1988 & 25,991 & 48,878 & 74,869 & $4.4 \%$ \\
\hline 1989 & 19,321 & 50,189 & 69,510 & $-7.2 \%$ \\
\hline 1990 & 13,510 & 44,415 & 57,925 & $-16.7 \%$ \\
\hline 1991 & 13,237 & 40,724 & 53,961 & $-6.8 \%$ \\
\hline 1992 & 13,093 & 39,076 & 52,169 & $-3.3 \%$ \\
\hline 1993 & 15,409 & 41,932 & 57,341 & $9.9 \%$ \\
\hline 1994 & 16,486 & 40,326 & 56,812 & $-0.9 \%$ \\
\hline 1995 & 13,498 & 41,138 & 54,636 & $-3.8 \%$ \\
\hline 1996 & 14,049 & 42,303 & 56,352 & $3.1 \%$ \\
\hline 1997 & 15,091 & 43,950 & 59,040 & $4.8 \%$ \\
\hline 1998 & 13,502 & 48,570 & 62,072 & $5.1 \%$ \\
\hline 1999 & 12,546 & 43,665 & 56,211 & $-9.4 \%$ \\
\hline 2000 & 12,124 & 44,976 & 57,100 & $1.6 \%$ \\
\hline 2001 & 12,412 & 44,382 & 56,794 & $-0.5 \%$ \\
\hline 2002 & 13,586 & 45,297 & 58,883 & $3.7 \%$ \\
\hline 2003 & 14,817 & 42,576 & 57,393 & $-2.5 \%$ \\
\hline 2004 & 18,315 & 44,922 & 63,237 & $10.2 \%$ \\
\hline 2005 & 18,742 & 47,395 & 66,138 & $4.6 \%$ \\
\hline 2006 & 19,061 & 50,957 & 70,018 & $5.9 \%$ \\
\hline 2007 & 18,096 & 51,572 & 69,668 & $-0.5 \%$ \\
\hline 2008 & 10,805 & 46,698 & 57,503 & $-17.5 \%$ \\
\hline 2009 & 8,560 & 40,910 & 49,470 & $-14.0 \%$ \\
\hline 2010 & 11,903 & 38,193 & 50,097 & $1.3 \%$ \\
\hline 2011 & 11,472 & 31,090 & 42,562 & $-15.0 \%$ \\
\hline
\end{tabular}

\section{RESEARCH METHOD}

\subsection{Research aim}

This research focuses on the 2008-2009 recession and also considers how approaches by large construction companies to deal with the threats of this downturn compare to the strategies employed in the previous one.

The main aim of the research is to discover how policies adopted by construction companies have changed and evolved from construction companies' practices of twenty years ago. In the paper, wider reference is also made to other sectors of the economy, experiences from other countries and underpinning theory of management strategies in response to business cycles.

\subsection{Business cycle management}

A trend in business management has been the adoption of business cycle management practices that deal with both opportunities and threats of the downturn. Such strategy can be developed and adopted by construction firms in a way that suits their operation during turbulent economic times. Several authors (such as Charan 2009; Colvin 2009; Leinwand, Mainardi 2010) have proposed that that there are always companies that not only survive and thrive in a crisis but can benefit from it 
and they have propounded views of how companies should respond and develop an appropriate strategy to deal with recessionary conditions. A study of the activities that organizations had undertaken during past crises by De Waal and Mollema (2010) provided a succinct summary view that there are basically six courses of action that companies can adopt in times of crisis, three of which are defensive based on a policy of survival (i.e. focusing on cost reduction, focusing on core operations and downsizing) and three of which are offensive with the company benefitting by growing profitably (i.e. strengthening the internal organization, focusing on increasing turnover and margin and exploiting opportunities).

\subsection{Comparison with studies of strategies during the previous UK business cycle}

The focus of this research is on the adoption of strategies by large construction companies, when faced with different phases of the business cycle. The research also aims to compare how these strategies may have changed since the previous cycle.

Concerning this earlier cycle (the 1986-1990 boom followed by the 1990-1991 recession), Hillebrandt et al. (1995) studied the effects of the recession on the behaviour of large companies in the construction industry and investigated how well theory and the accepted wisdom of appropriate strategies had stood up to changed circumstances. In conjunction with Hillebrandt and Cannon's earlier work (1990), they reported on two surveys undertaken (in 1986 and 1993-1994) and found major changes in strategy, when faced with the altered economic conditions. In 1986, during a period of boom, interviews were undertaken with twenty of the largest companies followed, in 1993-1994, after a recessionary period, by interviews with eighteen from the top fifty companies. This enabled a comparison between the situation in 1986, when the industry had experienced rising output for five years and the post-recession period, when the question of whether companies coming out of recession were fitter and leaner or weaker and thinner could be considered.

Relating the findings to Geroski's and Gregg's (1993) study of companies from a wide cross-section of industries, Hillebrandt et al (1995) found that changes in key areas of strategy between 1986 and 1993-1994 could be grouped into three categories:

Financial decisions: Greater focus on balance sheet matters and greater financial sensitivity. All large construction companies were forced into disposal of assets, whilst a large proportion of them had to raise funds through rights issues to reduce borrowing.

Strategic decisions: Greater focus on core business (with a reduction in the range of activities and disposal of marginal businesses) and changes to marketing strategies. Correcting the neglect of international markets meant that about a half of the companies developed overseas markets during that period.

Cost control: Pursuance of a policy of reducing permanent employment and reducing wage growth based on the impact of the lower workload on required staff levels.

The 1993-1994 interviews (Hillebrandt et al. 1995) also revealed the focus of the companies' strategies to be concerned with the development of new corporate objectives in the recessionary era.

For the current research, a questionnaire survey entitled the British economy boom and bust cycle: long-term impact and lessons for construction companies (hereinafter referred to as the 2012 Survey) was undertaken during the period December 2011 to June 2012 and, in the survey, companies were asked to report on the years 2005-2006 to 2010-2011. The survey split the period into two phases and gathered information on companies' actions and plans during the two phases. The growth phase of the business cycle was defined as the period to the end of 2008 Q1 (i.e. the 'boom' period) and the recessionary period as commencing 2008 Q2. The Hillebrandt studies had focused on the largest construction companies in the UK and so this survey targeted the largest construction companies in UK in order to allow comparisons with the findings from the earlier study.

\subsection{Research design}

A questionnaire survey was chosen as the main tool for data collection and large UK construction companies were the targeted respondents. Invitations to participate in the questionnaire survey were issued to all the companies listed in the 'Top 100 construction companies 2011' (ranked by turnover) provided by the Construction Index (2012). The survey elicited a response from thirty companies and the respondents were all drawn from the senior executive teams including managing directors, commercial directors, operational directors and business development directors. The questionnaire comprised forty nine questions covering background information on the companies 
and their views on the boom scenario ending in $2008 \mathrm{Q} 1$ and the recessionary period that followed. Questions varied between rating questions, ranking questions, selecting the best answers with an opportunity to opt for 'other' answer and an open question to record personal experiences and notes from both periods from each respondent. The majority of the responses came via a directed email approach but a few were collected via a structured interview using the questionnaire. (It had been clear from the pilot study that some respondents were more encouraged to engage and respond when a structured interview was setup). Companies' financial reports, statistics from the Office of National Statistics, Bank of England reports and other international organizations' reports provided important additional economic data.

A feature of the survey was that the companies participating in the survey (thirty of the top one hundred in the UK) constituted a broad spread of organizations incorporating twelve general contractors, nine house builders, four developers, specialist contractors and five utility service providers, thus ensuring a comprehensive industrywide view. Many of them are providers of more than one kind of construction service e.g. contracting and development, housing and repair/maintenance, buildings and rail, rail and infrastructure, contracting and manufacturing etc. (Note that the categorisation of participants is based on their own choice of label for their main activity).

These thirty companies, with an aggregate turnover in 2011 of more than $£ 25$ billion (The Construction Index 2012), deliver a considerable amount of UK construction works, especially the high value and landmark projects. They have a wide geographical presence within the UK, and most extend their scope overseas.

In the following sections, the construction companies' strategies during the previous business cycle (pre- and post-1990-1991 recession) are discussed followed by an appraisal of the construction companies' policies during the period 2000-2011, based on the survey result, including both the growth period and subsequent recession in 20082009 .

\section{THE 1990-1991 RECESSION AND THE PRECEDING PERIOD OF GROWTH}

Hillebrandt's and Cannon's (1990) work was concerned with both the impact of the 1990-1991 recession and the reactions of construction companies in the years that preceded it. During the period be- fore the 1980s boom, construction companies had been affected by the decline in public sector demand from the mid-1970s and many attempted to diversify into other types of construction work and away from civil engineering, notably into property development and housing. Many of them decided to diversify out of construction into other activities, some of which still related to construction in some way, but others in quite separate industries. It is noteworthy that all the companies interviewed by Hillebrandt et al. (1995) had an overseas operation and it was notable that contracting had ceased to be a dominant activity in some construction companies.

In responding to the boom, some common policies, adopted by the companies interviewed, were identified (Hillebrandt, Cannon 1990):

- To react to opportunities arising, there was a planned approach by some companies but in others, opportunities were dealt with as they presented themselves.

- The main objective of the financial policy in large construction firms was to find suitable outlets for a positive cash flow away from the contracting side of the business. All firms recognized the crucial aspect of positive cash flow and took some action to take advantage of these benefits.

- An increasing number of contracts were being awarded on the basis of negotiations, mostly with repeating old clients.

- Marketing was considered by far the weakest function. There were different practices, while some developed really a rigorous marketing function, others just seemed to be concerned with promotion of company image.

- The importance of human resources and especially of management contrasted strongly with the fact that, in most companies, personnel functions seemed inadequate. The nature of the contracting industry meant that direct long term employment of labour for all work was not popular. Labour only subcontracting largely replaced casual direct employment as the means of overcoming this problem. There was also a movement towards more supply and fix subcontracting, partly because of the growth of management contracting.

After the housing and property development booms of the $1980 \mathrm{~s}$, the tighter monetary policy that followed it led the UK economy into recession in 1990 (Chamberlin 2010). As conditions changed from boom to recession, companies were forced to move quickly to reduce debt, make cost savings, offload staff and restructure in order to rebuild and 
balance their businesses in an attempt to achieve comparative advantage.

For the recessionary period, Hillebrandt et al. (1995) considered some of the theoretical approaches and assessed companies' actions in the following aspects:

- The objectives of companies changed from growth to survival and that implied concentration on financial matters.

- In a difficult cash flow situation, cash must be realized for survival, in this case to pay off loans and so reduce gearing. So what mattered, in the decision to either keep or sell businesses, were market values and market prospects.

- The collapse of the commercial and house building market forced contractors to focus much more on their own competitive advantages and also on different ways of offering their services.

- In the boom years, companies had over-borrowed and over-invested. During the down turn in activity almost all firms shifted the emphasis of their strategy to dealing with balance sheet problems including reducing gearing by sale of assets and obtaining other finance.

- Pricing policy differed between boom and recession time. In recession, contractors had to concentrate on reducing cost by lowering overheads, cutting back support staff, closing down offices, freezing salaries, cutting back on company cars and other employee benefits.

- During the recession the over heavy management structure was slimmed down and financial controls actively strengthened.

- One of the negative effects of the recession was the decline in training activities and low levels of recruitment of young people.

\section{THE PERIOD 2000-2011: FROM ECONOMIC BOOM TO RECESSION}

\subsection{The findings of the 2012 Survey - the British economy boom and bust cycle: long-term impact and lessons for construction companies}

This survey was undertaken in 2012 in order to assess the reactions of large construction companies to the most recent business cycle (over the period 2000-09), in terms of distinguishing (as with Hillebrandt et al. 1995 earlier work on the previous cycle), between the two aspects of boom and recession.

\section{The 'boom' scenario}

The relevant boom years are the period during the first decade of the century until the commencement of the recession in 2008 Q1. One section of the survey elicited information on the impact of the boom years of the business cycle in terms of the effect on demand, turnover, profit, competition and costs. The focus was on the opportunities presented during that period and on the actions and strategy of the companies.

The majority of the construction companies (53\%) considered a notable increase in public and / or private sector demand for construction work to be the first indicator of the boom conditions. It is notable that, while $96 \%$ of companies indicated that the boom situation resulted in an increase in turnover, only $77 \%$ found that their company profit increased. This raises issues about the efficiency of the other companies, where the increase in turnover did not go hand-in hand with a higher level of profit. Some companies indicated that they diversified or expanded their operation during the boom, with a resultant increase in turnover, but admitted that they may have relaxed some financial management control in the process.

It was agreed by $70 \%$ of the contractors that tender prices were higher during the boom, but only $37 \%$ said that they charged a higher mark-up on contracts. A similar percentage said that there is less competition for winning projects during the boom. In contrast to this view, $40 \%$ stated that there was fierce competition in some sectors and less competition in others and hence charged variable mark-up depending on the type of work. Increases in tender prices can then be explained, in some cases, by other factors such as higher prices for materials (reported by $90 \%$ ) and an increase in prices of subcontract works (90\%). Unsurprisingly, the group of contractors who charged a higher mark up during the boom formed the majority of those who reported an increase in their profit level.

Opportunities during the boom period

Companies were asked to give their view of the opportunities present during the boom period and the top ten of these are summarised in Table 2.

Looking at the top five opportunities, the significance of the boom times for the companies in terms of the potential to strengthen the business was apparent. The majority of companies agreed on the significance of the increased demand for construction work. Building a strategic client relationship and positioning the company in the preferred market were both strategic business targets and were prioritised by the companies. The com- 
Table 2. Opportunities during the boom period

\begin{tabular}{ll}
\hline Opportunity & Rating (\%) \\
\hline $\begin{array}{l}\text { Increased demand for construction } \\
\text { Opportunity to build a relationship }\end{array}$ & 96 \\
with strategic clients & 91 \\
$\begin{array}{l}\text { Opportunity to position the company } \\
\text { in the preferred market }\end{array}$ & 83 \\
$\begin{array}{l}\text { Potential to increase the company's profit } \\
\text { Potential to increase the company's }\end{array}$ & 80 \\
turnover & 78 \\
$\begin{array}{l}\text { Opportunities for expanding in other } \\
\text { construction businesses }\end{array}$ & 63 \\
$\begin{array}{l}\text { Opportunities for improving } \\
\text { the business capability }\end{array}$ & 60 \\
$\begin{array}{l}\text { Less competition for winning work } \\
\text { Easy availability of borrowing }\end{array}$ & 53 \\
$\begin{array}{l}\text { Opportunities for expanding into other } \\
\text { non-construction businesses }\end{array}$ & 50 \\
\hline
\end{tabular}

panies' responses also confirmed the potential to increase the company's turnover and profit. Other opportunities mentioned, included: expansion into other construction businesses, opportunities for improving the business capability, less competition for winning work and easy availability of borrowing. Over a third of the construction companies took the opportunity during the boom to expand into other non-construction areas of business.

The responses showed that, during the boom of the 1980s, companies took the opportunity to maximize profit and cash flow. They realized the opportunity offered by expansion of the contracting business to facilitate investment in other businesses such as property development, housing and plant or equipment. The contractors also sought the opportunity to expand their role in the construction process to that of initiator in addition to expansion of their market. Between the two periods (1980s and 2000s) there are large similarities in the policies adopted by construction companies, despite emphasis in the latter period on certain policies, such as building strategic business relationships and improving business capabilities as an additional advantage. In both scenarios the realization of the opportunities is not a difficult task but rather the task of adopting appropriate strategies that will maximize the gains from those opportunities seems to be the main issue.

\section{Company strategy during the boom period}

Most of the construction companies (70\%) reported that they responded to the opportunities and threats as they arose or developed new strategies, once they recognised the boom conditions, compared to $27 \%$, who stated that a strategy for dealing with a boom period actively was part of the company's strategic business plan. This presents a picture of an industry that does little planning to manage its future and also raises a question about the potential for success of such a position in a resource demanding industry such as construction.

Almost a half (44\%) of the companies stated that growing their profit was the overriding objective during the boom period. This contrasted with $7 \%$ who prioritised turnover growth and clearly reflects a high consciousness about the importance of profit. A further $17 \%$ expressed a joint concern for profit and turnover maximization in their response. However, 20\% stated that the company objective didn't change during the boom. The strategy for achieving the financial objective was greatly dependent on concentrating on the core business $(83 \%)$. This policy was contrary to the diversification approach noted in the 1980s by the Hillebrandt and Cannon (1990) research. Lessons seem to have been learnt from the experiences of many companies who had followed the diversification route during the boom but had become failed businesses when the recession arrived.

In the 2012 Survey, some companies responded by investing in building their own capability (47\%) and $(37 \%)$ invested in other new construction related business. Other aspects of strategies during the boom, included: seeking mergers with or acquisitions of other businesses (28\%), exploring overseas business opportunities (27\%) and expanding in the growth business areas (24\%).

Looking at the range of policies adopted across the main functions of the companies, the following top ten actions, shown in Table 3, were identified.

The responses in Table 3 show that the boom period encouraged companies to work with the supply chain and develop that relationship (87\%). The other notable actions were to do with resources the recruitment of staff to cope with the extra load $(80 \%)$ and continual review of health and safety policy (83\%). The next three actions in terms of importance were to do with the management of their dealings, viz: considered carefully the client ability for payment (77\%), reviewed actions to ensure positive cash flow (73\%) and reviewed which contract terms are not acceptable during the boom (83\%). The latter actions indicated the important role of commercial management in boosting the company's profitability.

The remaining actions concerned: site management focusing on delivering quality projects (70\%), commercial management review of project risks to 
Table 3. Actions during the boom

\begin{tabular}{ll}
\hline Action & Rating (\%) \\
\hline $\begin{array}{l}\text { Continued to work with the supply chain } \\
\text { from their approved list }\end{array}$ & 87 \\
$\begin{array}{l}\text { Continually reviewed health and safety } \\
\text { policy to reduce incidents }\end{array}$ & 83 \\
$\begin{array}{l}\text { Considered the necessity of recruiting staff } \\
\text { to cope with potential extra workload }\end{array}$ & 80 \\
$\begin{array}{l}\text { Considered carefully the client ability to } \\
\text { make payment }\end{array}$ & 77 \\
$\begin{array}{l}\text { Reviewed actions to ensure positive cash } \\
\text { flow }\end{array}$ & 73 \\
$\begin{array}{l}\text { Reviewed and considered which contract } \\
\text { terms are not acceptable during the boom }\end{array}$ & 73 \\
$\begin{array}{l}\text { Site management focused on delivering } \\
\text { quality projects }\end{array}$ & 70 \\
$\begin{array}{l}\text { Reviewed project risks and ensured less } \\
\text { risk is borne by the company }\end{array}$ & 67 \\
$\begin{array}{l}\text { Reviewed employee wages and benefits to } \\
\text { retain and attract the best staff }\end{array}$ & 67 \\
$\begin{array}{l}\text { Selected carefully the list of approved } \\
\text { suppliers and contractors }\end{array}$ & 67 \\
\hline
\end{tabular}

ensure less risk is carried (67\%), reviewing employee wages and benefits to retain and attract the best staff and lastly selecting carefully the list of approved supplier and subcontractor (67\%). All of these listed actions are consistent with the broad key strategy of concentrating on the core business and the objective of profit maximization.

\section{Impact of the recession}

An interesting aspect of their perceptions of the impact of the boom period on their company was the fact that, even though the recession began in 2008 Q2, 61\% of the construction companies reported that they only began to feel the recession's effects more than twelve months later (i.e by 2009 Q2) and $17 \%$ only by 2010 Q2. Respondents were questioned about the initial signs of a downturn. A decrease in public and private sector demand for construction projects was the most strongly perceived early warning (47\%). Attention to other warnings such as the announcement of a central government budget with fiscal and monetary policy changes and perceived slow economic growth alone was low ( $7 \%$ and $13 \%$ respectively). This supports the conclusion that it takes some time often for the monetary or fiscal policy to start impacting on construction companies.

The recessionary period brought with it shrinkage of demand for construction work, with a $16 \%$ reduction in construction work over the period 2008 Q2 to 2009 Q3 (Office for National Statistics 2012), and the survey sought to discover the reac- tions of companies to the recessionary conditions. The survey was also concerned with what the companies perceived to be the threats presented by this downturn in activity.

The feedback from respondents in the 2012 Survey revealed that $40 \%$ of companies had a level of turnover in 2010-2011 that was either higher than, or did not change from, their peak turnover during the boom years, yet $73 \%$ reported a drop in their profit. The fact that $40 \%$ did not suffer from the recession impact - their turnover is either higher or stable - and a further $27 \%$ didn't report a drop in profit raises a question about the reasons. Some of the comments from company directors, contributed in the survey, helped to shed light on some of these factors that have helped those contractors to remain competitive during such a hard time.

This indicates that the biggest impact on the companies of the recession was in the profit drop rather than the impact on turnover. Another possible explanation is that the impact of a recession on large construction companies lags behind the other industries because these companies continue to deliver a stock of existing projects pre-planned for several years.

Explanations from executives of the respondent companies attributed this to such factors as:

- The real impact on the recession was yet to reflect on their turnover, even with the economy well into a recessionary period.

- The portfolio of the companies extended to other sectors or geographies that were unaffected so far by the recession.

- The companies took a number of steps to rationalise their expenditures and increase efficiencies.

- Contracts won during the recession generated higher profit as the continued reduction in prices of subcontract works allowed buying gains.

It was stated by $74 \%$ of the construction companies that tender prices levels were generally lower during the recession and that they, in turn, charged a lower profit mark-up. A large majority of the companies (90\%) indicated that the prices for subcontractor works decreased, while $51 \%$ said that material prices decreased. However, there was a lack of consensus on material prices, as $22 \%$ stated that material prices increased due to rises in the prices of oil and other materials worldwide. This diversity of view was obviously dependent on the companies' specific areas of work in the construction industry. 
Table 4. Threats during the recession

\begin{tabular}{ll}
\hline Threat & Rating (\%) \\
\hline Tough competition for winning jobs & 97 \\
Potential reduction in company profit & 93 \\
Decreased demand for construction & 93 \\
Risk of failure in the supply chain & 87 \\
Uncertainty of the economic conditions & 80 \\
Losing strategic relationships with clients & 67 \\
Potential reduction in company turnover & 63 \\
Losing market grounds to competitors & 56 \\
Clients defaulting on their payment & 47 \\
Challenge to the survival of core & 47 \\
construction business & \\
\hline
\end{tabular}

The feedback, regarding the degree to which those who work in different sectors felt that activity in the sectors had fallen, indicated severe shrinkage in new public construction $(60 \%)$, new private construction (57\%), the house building sector $(50 \%)$ and, to a lesser extent, in civil engineering and infrastructure and (17\% and 13\% respectively). Respondents, though, reported minimal or no shrinkage in the areas of specialist trading, facilities management and the manufacture of building materials.

The companies were asked to comment on the threats posed by the recession and their perception of the significance of the top ten threats are summarised in Table 4.

Almost all companies perceived tough competition as the biggest threat. A number of other perceived important threats related to the difficulty of the economic situation i.e. potential reduction in company profit, decreased demand for construction, uncertainty of the economic conditions and potential reduction in company turnover.

Many of the companies were concerned with the potential failure of an element in their supply chain. From the other angle, some contractors (47\%) were also concerned with the ability of their clients to continue with their due payment. This reflects the difficulties facing companies during the recession having to fight on different fronts in order to survive. This justifies the view shared by a considerable percentage (47\%), who saw the threat of the recession manifesting itself as a challenge to the survival of the core construction business.

\section{Company strategy during the recession}

When asked how they dealt with the recession scenario, companies were fairly evenly split along three lines according to their degree of planning for the recession, as follows:
- Strategy for dealing with the recession was part of the company's strategic business plan (30\%).

- Plans were redrawn once the recession scenario was realized (35\%).

- Responded to the opportunities and threats as they arose (35\%).

When asked about their objective, $47 \%$ had a profit-centred objective i.e. achieving a set level of minimum profit, maintaining the current level of profit or growth of profit and $10 \%$ stated that their objective was to survive and be able to cover their costs.

Overall, as shown in Table 5, the actions were aligned with the challenges that were facing the companies, which put the pressure on management to improve efficiency and deliver projects that contribute to the company success in building good relationships with clients and improving financial gains. The actions also emphasised the role of the commercial management team in improving commercial management by ensuring positive cash flow, reviewing client ability to make payment and reviewing project risks. The role of the business management was still paramount in developing the relationship with the existing clients and seeking partnership with others. It is notable that the concentration on business development was on the relationships with the existing clients rather than attracting new ones.

The final question in the survey dealt with rating the policies that the companies considered would be most likely to offer protection from the problems caused by the fluctuations of the business cycle. Table 6 shows the actions considered to be most important.

A feature of the responses was that a significant proportion companies still did not appear to be pursuing policies important for protecting their business from the turbulence of the economic cycles i.e. developing a leaner business and building the right skill base. Both policies were considered extremely important by only $70 \%$ leaving $30 \%$ without strong commitment to these policies. An international survey (KPMG 2010) stressed the importance of such policies for companies in times of economic downturn as well as the important role of investing in risk management, which was rated by only $50 \%$ as extremely important action in the 2012 Survey. Policies, such as 'getting ready for change' in order to offset risk from business cycles were rated extremely important by $60 \%$. Wong and Logcher (1986) commented that, in the uncertain construction business environment, maintaining a 
Table 5. Actions undertaken during the recession

\begin{tabular}{ll}
\hline Action & Rating (\%) \\
\hline Reviewed actions to ensure positive cash flow & 93 \\
Continually reviewed health and safety to reduce incidents & 90 \\
Concentrated on developing the relationship with existing strategic clients & 90 \\
Site management focused on delivering quality projects to meet client expectations & 83 \\
Considered carefully the client ability to make payment & 82 \\
Site management prioritised achieving good company image and good relationship with the client & 77 \\
Exerted additional efforts to reduce waste & 77 \\
Sought partnership with clients & 77 \\
Reviewed carefully project risks and ensured less risk is carried by the company & 77 \\
Site management prioritised to achieve lowest construction cost and higher profit & 73 \\
Considered carefully the payment terms & 73 \\
Reviewed and considered carefully which contract terms were not acceptable during the recession period & 73 \\
The company continued to work with the supply chain from the approved list & 73 \\
\hline
\end{tabular}

Table 6. Policies to immunise against the effects of the business cycle

\begin{tabular}{ll}
\hline Policy & Rating (\%) \\
\hline Building strategic business relationship and partnership with clients and the supply chain & 83 \\
Evaluating and exploiting future demand & 78 \\
Demonstrating good corporate ethics & 70 \\
Developing a leaner business & 70 \\
Building the right skills & 70 \\
Getting ready for change & 60 \\
Seeking innovation in sustainability & 53 \\
Applying the lessons of the past to the vision of the future & 52 \\
Investing in risk management & 50 \\
\hline
\end{tabular}

sufficient cushion for uncertainty is crucial. They highlighted that this could be achieved by flexibility in human resources, flexibility in cost structure, flexibility in financial structure and diversification by line of business.

The 2012 Survey revealed important commonalities during both the boom and the recession with profit being the overriding focus of the companies and the strategies to achieve the profit objectives being generally based on concentration on core business during both the boom and recession.

The following section discusses the common themes from the two business cycles during the 1990s and 2000s.

\section{COMMON THEMES FROM THE TWO BUSINESS CYCLES}

\section{Common themes of the boom periods}

The investigations by Hillebrandt and Cannon (1990) into the factors affecting, and actions undertaken by, large companies during a period of strong economic growth found that some companies had a planned approach to take advantage of the conditions. Yet in other companies, opportunities were considered as they presented themselves.

As already indicated, the findings of the 2012 survey showed that about two thirds of the companies responded to the opportunities provided by the boom conditions as they arose, and almost one third indicated that it was part of company strategy. Hillebrandt and Cannon (1990) reported that all firms recognized the crucial aspect of positive cash flow and took the necessary actions for its attainment. In 2012, however, only $74 \%$ of the companies reviewed actions to ensure positive cash flow. This reduction in attention to cash flow between the 1995 and 2012 surveys may be related to the lower level of profit reported during the growth period even though all companies agreed that their turnover increased during that period. 
It appeared that, for some companies, the effort to increase turnover was at the expense of ensuring effective governance which led to loss of profit by some companies.

The 1990 study reported marketing to be by far the weakest function and in need of attention by policy makers. Evidence of the same is noted in the 2012 survey with $70 \%$ concentrating on developing the relationship with the existing clients and bidding only for selected clients, while only $41 \%$ sought new strategic clients. Companies should widen their strategic relationship (new and existing) during the boom and work on maintaining this relationship, in order to provide a safety net during economic slowdown.

Although there is a general awareness of the importance of human resources and especially of their management, the 1990 study found that, in most companies, personnel functions seemed inadequate. In the 2012 survey, there was a notable emphasis on human resources during the boom time. However, this can be placed against the recent background of reduced attention to training and apprenticeship opportunities. Generally, human resource development and recruitment has to consider carefully the long term plan of the company due to the significant cost of retaining, recruiting and developing staff. The stop-go nature of the industry is a factor that leads to under-investment in human resources and a reliance on recruitment to fill gaps.

A comparison between the 2012 list of top companies and those from the last recession shows that twenty seven of the thirty five top companies in Hillebrandt and Cannon's study have disappeared or been subjected to mergers or acquisitions by 2012, which may help to explain the absence of a major shift in the approach towards the recession and the repetitiveness of some of the old policies that were tried in 1990s.

\section{Common themes of the recessions}

In addition to Hillebrandt's studies of the UK construction industry (Hillebrandt, Cannon 1990; Hillebrandt et al. 1995) other studies from a variety of countries (see Wong, Logcher 1986; Mills 1997 on the USA; Boon 1996 on New Zealand; Low, Lim 2000; Lim et al. 2010 on Singapore; Ocal et al. 2006 on Turkey) have identified common elements in the strategies of construction companies in recessionary periods.

In addition to the present study and the UK study on the impact of the early nineties recession by Hillebrandt et al. (1995), Lim et al. (2010) studied the survival strategies of large and me- dium contractors in Singapore (which had suffered a long recessionary period from 1997 to 2005) and grouped the actions into the same categories in the Hillebrandt study. From these three studies some common policies can be noted.

In terms of financial actions, the disposal of assets and rights issues was reported by Hillebrandt et al. (1995). There was no evidence of such actions in the Singapore study, in which the top financial action was the securing of additional funds by creating uncommitted financial resources (82\%) and negotiating alternative loan services (74\%). In our 2012 survey, there was a notable attention to ensuring positive cash flow including considering carefully payment terms (93\%) and consideration of clients' ability to make payment (82\%). A number of respondents indicated their positive cash flow position and non- dependency on loans from banks. A positive cash flow was viewed by a number of executives as one of the main benefits for those who work in construction, while their profit margins are usually low compared to other industries. This view was expressed by Hillebrandt (1984), commenting about the level of profit in the construction industry compared to other industries.

Focusing on core business during the recession was emphasised by all companies in 1995 against $77 \%$ in the 2012 survey. Change of marketing strategy was reported by all companies in 1995 and a policy to consider overseas policy was adopted by half of the companies (similar to the level found by Lim et al. 2010) compared to the much smaller $26 \%$ in the 2012 survey. This percentage was equivalent to the $60 \%$ of those, who already had overseas businesses i.e. the policy of expanding overseas was only popular with those, who already had some business presence overseas.

During the recession, to secure projects, contractors may make the lowest bids to win the projects. This practice was not reported in the 1995 study but $88 \%$ of companies were reported to have done so by Lim et al. (2010). Also, $67 \%$ of contractors in a global survey by KPMG (2009) reportedly did so but $67 \%$ of the contractors in the 2012 survey refuted this strategy of bottom price bidding with tiny or zero profit and it is notable that both private and plc companies shared the same view an indication that contractors do not prefer this desperate action of buying work. An important factor in adopting such action is the length and depth of the recessionary period. The longer and deeper is the impact on a company, the greater the need for more radical action. From 1990 it took forty four months for GDP to return to its pre-recession 
level (Chamberlin 2010). The weakness of the prolonged recovery from the 2008 (and ensuing) recession indicates that it would not be surprising to see the return of such approaches.

Cost control actions were reported as important in all the studies. The obvious reason is that, in recessionary times, raising profit is challenging, when there are less projects and turnover decreases. Cost control is not only a way of achieving and raising profits but is also an important measure to prevent losses. In the 1995 study, all participants reduced employment, employee salary growth and head office overhead costs. Lim et al. (2010) noted that three actions had been adopted by all firms, viz: implementing stricter site management to reduce material wastage, stricter financial management on company cash flow and stricter procurement procedures. In the 2012 survey, stricter financial management on cash flow was adopted by $93 \%$ and $77 \%$ adopted policies to control waste on site.

There was a notable difference between the two UK studies in human resource management. Reducing employment dropped from 100\% in 1995 to $69 \%$ in the 2012 study, which represents a shift in appreciation of the role of the competent staff in anticipation of the eventual return to a higher activity level.

A trend in business management in recent years has been promotion of the adoption of businesscycle management practices that deal with both opportunities and threats of the downturn relating to Navarro's et al. (2010) distinction between the master cyclist approach based on the view that, when the economy heads towards recessions, the best companies look for opportunities whereas the reactive cyclist focuses on cost cutting measures This strategy can be developed and adopted by construction firms in a way that suits their operation during turbulent economic conditions. Some executives during the 2012 survey noted the benefits in recession of recruiting competent staff and training others in anticipation of the future upturn in business.

\section{CONCLUSIONS}

The 2012 survey and the earlier research by Hillebrandt both revealed that the companies considered carefully their operation and reviewed their practices in terms of what they were doing and how they were doing it. Both survey reports concluded that, in these challenging markets, construction businesses should adopt sustainable strategies such as evaluating and exploiting future demand, developing the right skill-set, continuing to invest in risk management and ensuring fully integrated risk management.

This research revealed the challenges that face construction companies and the policies adopted to face those challenges. The 'boom and bust' conditions are extreme conditions of the economy and policies under each type of condition have been tailored by the companies to weather the economic cycle with the basic aim (in some instances) of securing the business's existence rather than looking at the long term view. The options of policies have also changed over the time due to the changing circumstances.

In 2012 , the two policies, which were identified by most of the survey participants as being the most important to protect the companies from cyclical fluctuations were building the right skillset and developing strategic business relationships. Those companies that have built and maintained a strategic client relationship are in a better position to deal with a recession. Also, it is evident that diversification has helped companies to deal with cyclical changes in the economy. Two further actions were rated highly by the executives of the companies - developing a leaner business and demonstrating good corporate ethics. A major change over the last two decades has been the rise of social responsibility and sustainability on clients' agenda, which is reflected in the strong support of $53 \%$ of the companies in the 2012 Survey. These policies were not referred to in the earlier studies.

Construction activity often has a high degree of volatility and the various challenges that face construction companies environment during the course of their operations are made even more complex by the competitive during downturns in the economy but it also vital that companies are prepared for the upturn, in order to take advantage of the situation. However, a reactive approach rather than a planned approach seem to have been dominant. Few steps appear to have been taken by management of the companies to ensure a long-term strategic vision.

This research highlighted key areas which construction companies need to consider, if they are to learn from their experiences during the business cycles, as optimistically expressed by the $87 \%$ of those surveyed, who supported the paradigm of applying the lessons of the past to the vision of future. 


\section{REFERENCES}

Barras, R. 2009. Building cycles: growth and instability. London: Wiley-Blackwell.

Boon, J. 1996. Survival strategies for small firms in a volatile market, in D. A. Langford, A. Retik (Eds.). The organization and management of construction: shaping theory and practices. London: Spon.

Carassus, J.; Andersson, N.; Kaklauskas, A.; Lopes, J.; Manseau, A.; Ruddock, L.; de Valence, G. 2006. Moving from production to services: a built environment cluster framework, International Journal of Strategic Property Management 10(3): 169-184. http://dx.doi.or g/10.1080/1648715X.2006.9637551

Chamberlin, G. 2010. Output and expenditure in the last three UK recessions, Economic and Labour Market Review 4: 51-64. http://dx.doi.org/10.1057/ elmr.2010.113

Charan, R. 2009. Leadership in the era of economic uncertainty. New York: McGraw-Hill.

Classessens, S.; Kose, M. A.; Terrones, M. E. 2009. What happens during recessions, crunches and busts?, Economic Policy 24(60): 653-700. http://dx.doi. org/10.1111/j.1468-0327.2009.00231.x

Colvin, G. 2009. The upside of the downturn: ten management strategies to prevail in the recession and thrive in the aftermath. London: Nicholas Brearley Publishing.

Dale, S. 2009. The current downturn - a bust without a boom?, in The Association of British Insurers Economic and Research Conference, 27 March 2009, ABI, London.

De Waal, A.; Mollema, E. 2010. Six courses of action to survive and thrive in a crisis, Business Strategy Series 11(5): 333-339. http://dx.doi. org/10.1108/17515631011080740

Geroski, P. A.; Gregg, P. 1993. Coping with the recession, National Institute Economic Review 146: 64-75. http://dx.doi.org/10.1177/002795019314600105

Gruneberg, S. L.; Ive, G. J. 2000. The economics of the modern construction firm. London: Macmillan.

Hillebrandt, P. 1984. Economic theory and the construction industry. London: Macmillan.

Hillebrandt, P. M.; Cannon, J. 1990. The modern construction firm. London: Macmillan.

Hillebrandt, P. M.; Cannon, J.; Lansley, P. 1995. The construction company in and out of recession. London: Macmillan.

International Standard Industrial Classification. 2008. Statistical papers series M NO.4/Rev. 4, Department of Economic and Social Affairs, Statistics Division. New York: United Nations.
KPMG. 2009. Navigating the storm: charting a path to recovery: Global construction survey. KPMG International.

KPMG. 2010. Adapting to an uncertain environment. Global construction survey. KPMG International.

Leinwand, P.; Mainardi, C. 2010. The essential advantage: how to win with a capabilities-driven strategy. Cambridge: Harvard Business Review Press.

Lim, B. T. H.; Oo, B. L.; Ling, F. 2010. The survival strategies of Singapore contractors in prolonged recession, Engineering, Construction and Architectural Management 17(4): 387-403. http://dx.doi. org/10.1108/09699981011056583

Low, S. P.; Lim, N. H. 2000. The strategic responses of construction firms to the Asian financial crisis in 1997-1998, International Journal of Construction Marketing 1(2): 1-12.

Mills, Q. 1997. Staying afloat in the construction industry. Los Angeles: BNI Publications.

National Bureau of Economic Research. 2012. US business cycle expansions and contractions [online]. Available at www.nber.org/cycles/cyclesmain.html [accessed 3 august 2012]

Navarro, P.; Bromiley, P.; Sottile, P. 2010. Business cycle management and firm performance: tying the empirical knot, Journal of Strategy and Management 3(1): 50-71. http://dx.doi.org/10.1108/17554251011019413

Ocal, E.; Oral, E. L.; Erdis, E. 2006. Crisis management in Turkish construction industry, Building and Environment 41(11): 1498-1503. http://dx.doi. org/10.1016/j.buildenv.2005.05.042

Office for National Statistics. 2012. Construction statistics [online]. Available at: http://www.statistics.gov. uk/statbase/product.asp/vlnk $=720$ [accessed 3 August 2012]

Office for National Statistics. 2013. Economic review, May 2013 [online]. Available at: http://www.ons. gov.uk/ons/dcp171766_308566.pdf [accessed 11 May 2013]

Ruddock, L.; Ruddock, S. 2009. The scope of the construction sector: determining its value, in Ruddock, L. (Ed.). Economics for the modern built environment. London: Taylor and Francis.

The Construction Index. 2012. Top 100 construction companies 2011 [online]. Available at: http://www. theconstructionindex/market-data/top-100-construction-companies/2010 [accessed 3 august 2012]

Wong, T. K.; Logcher, R. D. 1986. Contractors in cyclical economic environments, Journal of Construction Engineering and Management-ASCE 112(3): 310-325. http://dx.doi.org/10.1061/(ASCE)07339364(1986)112:3(310) 